\title{
Agricultural Extension Approaches to Enhance the Knowledge of Farmers
}

\author{
Kamalpreet Kaur* and Prabhjot Kaur \\ Department of Extension Education, Punjab Agricultural University, \\ Ludhiana 141004, Punjab, India \\ *Corresponding author
}

\section{Keywords \\ Extension approach, Agricultural technologies, Partnership and NGO's}

\section{Article Info}

Accepted: 20 January 2018 Available Online: 10 February 2018

\section{A B S T R A C T}

Public agricultural extension system is one of the largest knowledge and information dissemination institution. In the last 15 years, agricultural production has stagnated and this calls for a system based inter-disciplinary holistic approach not only to develop ecologically sound technologies for different areas, but also to facilitate their utilization at gross root level. Extension approach is like doctrine for the system, which informs, stimulates and guides such aspects of the system as its structure, its leadership, its program, its resources and its linkages. Various extension approaches completed successfully by giving satisfactory results in past to improve the farmers knowledge regarding newly developed agricultural technologies. Some of them are continuously running in present along with newly developed extension approaches and requires little modifications in future to increase the agricultural potential of country. The use of innovative extension approaches to increase coverage is, therefore, a concern for all involved in agriculture extension and advisory services. Participatory, partnership of government and non-government organizations (NGO's), farmer's cooperative approaches are running successfully in present. In the future, the social media, agricultural education, village panchayats, off-line initiation of ICT could be helpful for effective extension of agricultural information to the grass-root level. Cost recovery approach and sharing cropping approach should be followed at large level.

\section{Introduction}

Approach is like a doctrine for the system, which informs, stimulates and guides such aspects of the system as its structure, its leadership, its program, its resources and its linkages. According to Axinn (1988), the approach is the style of action within system. It's like the drummer which sets the pace for all activity of the system. Hagmann et al., (2000) explained an approach as a way in which different guiding principles are applied in a specific situation to fulfill different purposes. It consists of a series of procedures for planning, organizing and managing the extension institution as well as for implementing practical extension work by staff with technical and methodological qualification and using the necessary and appropriately adapted means. Various extension approaches completed successfully by giving satisfactory results in past to 
improve the farmers knowledge regarding newly developed agricultural technologies. Some of them are continuously running in present along with newly developed extension approaches and requires little modifications in future to increase the agricultural potential of country. In the present time the extension is done mainly by Public sector, Private sector and Public private partnership.

\section{Public extension}

State development departments

ICAR, State agricultural universities

Other cooperative agencies

\section{Private extension}

Privatization is the act of reducing the role of government on increasing the role of private sector in an activity or in the ownership of assets. Bloome (1993) reported that private extension involves personnel in the private sector that delivers advisory services in the area of agriculture and is seen as an alternative to public extension. Whereas, Vandenban and Hawkins (1996) observed that farmers are expected to share the responsibility for their services and pay all or part of the cost. In private extension, clientele are expected to pay for the service fee (e.g. Private Agricultural consultancies), or extension services provided for product promotion (e.g. Agri-business firms-seed companies), or for the procurement of farm produce (e.g. contract farming or free of cost extension (e.g. NGOs).

\section{Private agricultural consultancies}

Agricultural consultants or advisers offer advice, support and solutions to their clients to ensure their business or enterprise is running as efficiently and effectively as possible. Their clients may be farmers, landowners, other agricultural businesses in manufacturing and services (Singh et al., 2006).

\section{Agri-business firms}

Agro-input companies dealing with seeds, fertilizers, pesticides and agro-machinery perform extension as one of their function for marketing.

The inputs agencies are undertaking promotional activities through advertisement, organizing demonstration farmers meeting and seminars (Sulaiman and Vandenban, 2003).

\section{Contract farming}

Contract farming involves a forward contract according to which growers are committed to provide an agricultural commodity of a certain type at a certain time and price in a specified quantity to a known buyer, an agribusiness company (Singh, 2002).

A number of agro-processing and trading firms makes contract with the farmers to produce specific commodity and these firms after provide extension services as part of contract farming arrangement providing extension services helps in procuring adequate quantity with specified quality and type of produce or processing or trading in high value market.

To support growers in producing the specified commodities, companies can provide credit, inputs, and extension services such as new technologies (Asokan and Singh, 2003).

In Punjab, Pepsico first started contract farming for tomatoes in the early 1990s and now contracts farmers for potatoes and chillies. Pepsi's own research and development activities helped develop and disseminate new technologies, including agricultural practices such as deep chiseling and new seed varieties, through Pepsi field officers, field demonstrations, and booklets (Singh, 2002). 


\section{Non-Government Organizations}

It is any non-profit, voluntary citizen's group which is neither a part of a government nor a conventional for-profit business. NGOs may be funded by government, foundations, businesses or private persons.

Estimates of the number of NGOs active in rural development in India range from fewer than 10,000 to several hundred thousand depending on the type of classification used. Some 15,000-20,000 are actively engaged in rural development. India has a number of NGOs with varying levels of capacity, implementing a wide range of programmes. Wide variation in density of NGOs exists among states. NGOs receive funding from the Government and corporate bodies as well as international donors. Due to their effectiveness and flexible operational mechanisms, governments are increasingly finding partnering with NGOs attractive. Bharatiya Agro-Industries Federation (BAIF) is an important NGO working very actively. BAIF works on livestock development, water resource management, environmental conservation and livelihood development (Ferroni and Zhou, 2011).

\section{Public-Private Partnership}

Public-Private Partnership (PPP) describes a government service or private business venture which is funded and operated through a partnership of government and one or more private sector companies (Agarwal, 2011). Reasons for this change include the following: Budget deficits make it difficult for the government to pay for such a service.

It is hoped that by making extension agents accountable to farmers who are competent to judge the quality of their work, this in turn will make the extension service more efficient. Farmers are the main beneficiaries from extension services activities and therefore it is fair that they pay the costs.

\section{Agriclinics and Agribusiness Centres (ACABC)}

Agriclinics and agribusiness centers (ACABC) provide agricultural advisory services to farmers through technically trained agricultural graduates at the village level. Bank loans are available for the agripreneurs to start an agriclinic. The central government provides 25 percent of the cost as a subsidy. MANAGE is also very active in this. In addition, the states have adopted the approach add their own additional subsidies for agriclinic implementation. The objectives of the program are to supplement the public extension system, increase the availability of inputs and services for farmers, and provide employment to agriculture graduates (Anonymous, 2008). Discussion with officials in Maharashtra, Andhra Pradesh and Rajasthan cleared that increased productivity of crops in areas where agriclinics are available. According to the farmers, benefits obtained from agriclinics included optimum usage of farm inputs, plant protection, and increased productivity. Across the country, Uttar Pradesh has the highest number of agriclinics and agribusinesses.

\section{Cost-sharing approach}

This approach assumes that cost-sharing with local people (who do not have the means to pay the full cost) will promote a programme that is more likely to meet local situations and where extension agents are more accountable to local interests. Its purpose is to provide advice and information to facilitate farmer's self-improvement. This approach is based on local people sharing part of the cost of the extension program. Its purpose is to provide advice and information to facilitate farmers' self-improvement. Problems may arise if local 
farmers are pressured into investing in unproven enterprises (Feder et al., 2001).

\section{Farmer based extension}

\section{Farmer interest group}

A Farmer Interest Group (FIG) is a selfmanaged, independent group of farmers with a shared goal and interest. The members work together to achieve this goal by pooling their existing resources, gaining better access to other resources and to share in the resulting benefits. The joint action in financial activities like saving and interloaning can become model for future FIGs to help the resource poor farmers come out of debt-trap through mutual help. Regular meeting of group members is mandatory requirement to ensure smooth functioning of FIGs. Effective participation of members in meeting leading to consensus on various issues/problems, faced by of the group, is an important indicator of group health (Riar, 2006).

\section{Successful groups}

Bee keeping farmers interest group, village Dida, Block Dinanagar, Distt. Gurdaspur.

Dairy farmers interest group, Village Nandanpur, Block Jalandhar West, Distt. Jalandhar.

Malwa Gramin Honey producer farmer interest group, village Kaulseri, Block Dhuri, Distt. Sangrur

Malwa fruit and vegetable growers farmer interest group, Block Kotkapura, Distt. Faridkot.

\section{Farmer Field School}

It is a group-based learning process that has been used by a number of govt., NGOs, and international agencies. The first FFS was designed and managed by the UN Food and Agriculture Organisation in Indonesia in 1989 since then more than two million farmers across Asia have participated in this type of learning. FFS consists of 20-25 farmers who meet one morning every week for an entire crop growing season.

A FFS is facilitated by extension workers on skilled farmers. Employing non-formal education method, the field is used as the primary resource for learning (Vandenberg and Jiggins, 2007). Farmer field schools (FFS) are a participatory method of learning.

\section{Farmer to Farmer Communication approach}

Farmers show great interest on their fellow farmers. When one farmer share his progressive views with others, than it could work very effectively than any other method of technology sharing. The Adike Pathrike, a farm monthly started by all India growers associations to encourage farmer to farmer communication was one of the success story of farmer to farmer communication (self-help journalism) for more than 15 years of existence in agricultural knowledge dissemination. The uniqueness of publication is that starting from writing articles, editing, publishing and distribution are mainly shouldered by practicing farmers.

\section{Farmer Friend approach}

As a grass root part of ATMA the farmer Friend (FF) serves as a vital link between extension system and farmers at village level. FF will be available in the village to advice on agriculture and allied activities. The FF facilitates dissemination of information to farmers, individual farmers and farm women directly through one to one interaction individually or in groups. 


\section{Group approach}

The group approach programme encompassing several aspects of selfemployment such as organisation of the poor into self-help groups, training, credit, technology, infrastructure and marketing was evolved (Najamuddin and Guliani, 2006).

Self-help group is a homogenous group of rural people who voluntarily come together to form a group or association for their income generation and empowerment for achieving a common objective. SHGs are small in size with membership ranging from 10-25 (Mondal and Ray, 2009). One important example is "All Women's Dairy Co-operative of Majowal Majara village in Nawanshahr district in Punjab. Milk producers were mainly rural women who lack scientific know-how.

\section{Other valuable approaches}

\section{Farming systems approach}

The farming systems approach considers the farm, farm household and off-farm activities in a holistic way to take care of not only farming but all aspects of nutrition, food security, sustainability, risk minimization, income and employment generation, which make up the multiple objectives of farm households. This approach considers interdependencies of the components under the control of members of the household, as well as how these components interact with the physical, biological and socio-economic factors not under the household's control.

The farming systems approach emphasizes that research and extension agendas should be determined by explicitly defined farmers' needs through an understanding of existing farming systems rather than the perceptions by research scientists or extension functionaries (Meena et al., 2013).

\section{Mass media approach}

The all India Radio and Doordarshan transmit program on agriculture. DD Kisan channel is an Indian agricultural 24-hours television channel, was launched on $16^{\text {th }}$ May 2015 . The channel has been dedicated to agriculture and allied sectors, which disseminates real-time inputs to farmers on new farming techniques, water conservation and organic farming among other information (Anonymous, 2015). In print media Newspapers are also covering agriculture news items. Almost all dailies presently devote one page once in a week covering aspects of agriculture. Newspapers are published in local languages are the close friends of farmers to familiar them about new technology.

\section{Market-led extension approach}

It is an approach through which extension system reached to the clientele on an end basis, beginning from package of practices for production to selling of produce at the consumer's door so that the farmers can get remunerative prices for their produces.

Farmers are sensitized on the production aspects like (i) what to produce (ii) when to produce (iii) how much to produce (iv) when and where to sell. Besides this, farmers are also sensitized on consumer preference, market intelligence, processing and value addition and market information system. The market-led extension deals with all these parameters from production to marketing of agricultural produce (Swanson, 2008).

\section{Important market-led extension services in India}

\section{Dynamic Market Information (DMI)}

Tamil Nadu Agricultural University implemented a pioneer project called Dynamic 
Market Information (DMI) which aims at providing daily market prices for 160 selected perishable commodities in Tamil Nadu, Kerala and Karnataka. DMI provides market price information via SMS through mobile phones.

\section{Participatory approach}

Participation means that the poor people themselves are involved in identifying the problems they face, determining ways to overcome them, designing realistic plans to achieve these goals, and carrying them out. Solutions devised and fulfilled by the people in need are far more likely to prove successful than those imposed from outside. Participatory extension provides a framework for extension staff to participate with village communities in facilitating development planning and activity implementation.

This approach ensures the extension response become community driven and assist village communities implement their planned activities with routine monitoring and evaluation of activities. Importantly, as the name implies, the extension process is seeking maximum participation from women and men from all groups within the target village community. The aim of the approach is bringing about change in people's attitude which is critical on the part of the people involved towards their environment and adoption of interventions for agricultural development (Suzler, 1989)

\section{Project approach}

This approach concentrates efforts on a particular location, for a specific time period, often with outside resources. Part of its purpose is often to demonstrate techniques and methods that could be extended and sustained after the project period. It uses large infusions of outside resources for a few years to demonstrate the potential of new technologies.
Control is at the central government level and there are often considerable financial and technical inputs from an international development agency. Short-term change is the measure of success. In the aquaculture project in Nepal, for example, a loan from the Asian Development Bank was used by the Ministry of Agriculture to support extension work by fisheries officers in many different locations throughout the country. They were able to introduce pond fisheries through an effort which combined the project approach with the specialized commodity approach. One problem with this approach, however, is that a flow of ideas outside the project rarely occurs (Axinn, 1988).

\section{Cyber extension approach}

Cyber extension is defined as extension over cyber space, the imaginary space behind the interconnected telecommunication and computer networks (Mishra, 1999). Cyber extension approach includes effective use of Information Communication Technology (ICT), internet, expert systems, information kiosks and computer based training systems to improve information access to the farmers, extension workers, research scientists and extension managers.

\section{Suggestions to make the extension work more effective}

\section{Redefining the role of public extension}

There is an urgent need to redefine the role of public extension system because private extension providers such as: consultancies, agri-business and processing firms are increasingly concentrating on selected geographical area, crops and clientele. Hence public extension need to concentrate on resource poor farmers, food security issues, environmental extension and monitoring and regulatory roles of extension services. 


\section{Suggested Extension Model}

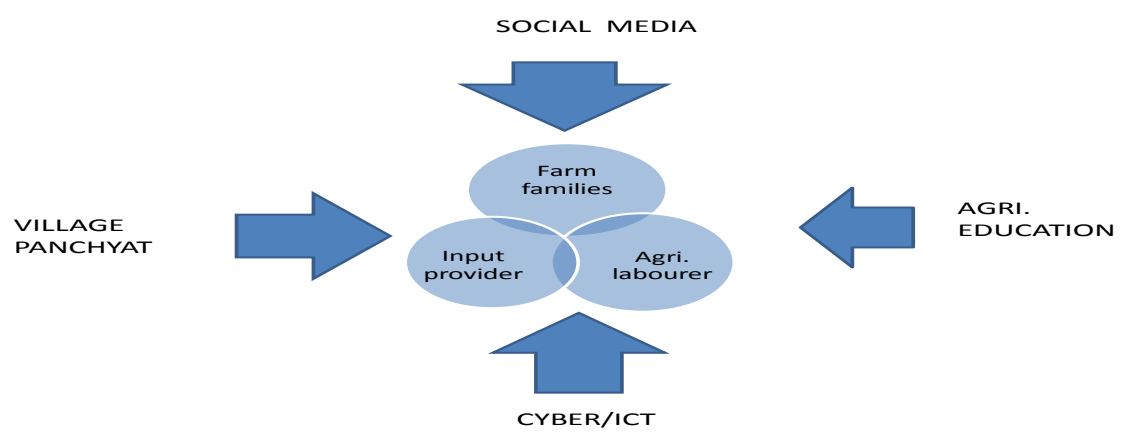

(By author)

For example Kaur, (2005) found that composition of farmer advisory committee (FAC) under ATMA was not strictly as per prescribed norms. Regarding conduct of meetings, as per norms there should be 60 meetings but in actual only 50 meetings were held and attendance in these meetings were found to be 62 per cent.

\section{Diploma in Agricultural Extension Services for Input Dealers (DAESI)}

Programme may be up scaled to entire country so that the services of input dealers can be utilized as Para extension workers at village level (Mehta, 2011).

\section{Awards}

May be instituted at different levels in recognition of services/achievement of farmers and extension service providers from different localities.

\section{Scaling-up of ICT initiatives}

Appropriate ICT models for agricultural extension need to be replicated and extensively used for farm information dissemination. Like e-Chaupal at the Panchayat level. Where the on-line access is not possible there should be off-line access at village level.

\section{Beyond technology transfer role, broad based extension}

Apart from farm information and technology dissemination, extension providers should concentrate on wider role including input supply, market intervention, and linking farmers for farm credit.

\section{Encouraging Multi Agency Extension Strategy}

Involving public/private extension service providers. E.g. ATMA made good access but proper spirit is lacked.

So there is a need to boost motivation dose for the various departments to work in flexible mode according to the work plan of ATMA.

\section{Addressing gender concerns}

Mobilizing farm women into groups. In all the training programme at all levels, women participation must be ensured.

Specialized training for women trainers, women farmers have to be organized. 


\section{Introducing cost recovery approach}

In the present time the farmers are willing to pay for better services, hence cost-recovery approach should be introduced at large level to ensure the financial sustainability of extension system and also increase the commitment of farmers.

\section{Share cropping system}

The extension worker provides advisory and inputs. Farmer uses his land and labour. Extension worker share the crop with farmer for a profit. Hired labour and other costs are shared. The extension workers using his link easily obtain farm inputs from input dealers even for credit until the harvest. Share cropped field serves as a demonstration plot. Since, extension worker has a personal stake, it motivates him to put maximum effort. Extension worker can also enter into agreement with as many farmers as he can, depending on his financial position and time (Prabhakar, 2010).

\section{Suggested Model}

Farm family, agricultural laborer and input supplier are the heart of this model. Ultimate aim of the extension approaches to disseminate the new technologies to the farmers and to convince them to adopt these ideas for their better development. For this the important component of this model are as follows:

\section{Social media}

With the popularization of new technologies and ICTs it is felt that there is a good scope for disseminating the information by various social apps like whatsup, face book, hikes etc. Farmers could make groups on social apps and could share their farm's status, newly followed technique at their farm with friend which will motivate the fellow farmers to adopt that new technique. Every farmer in our villages is not educated so gram panchayat could share with villagers.

\section{Agricultural education}

We all know the status of agricultural subject as an additional subject in the school curriculum. The teacher appointed for this subject is generally not belonged to the agricultural graduation. Then how we could expect the clearance of basic ideas of this field in mind of students at school level. There is a need to rethink and planned for proper qualification for agricultural teacher in school level. The other point is agriculture subject should be as compulsory subject rather than additional/choice subject at school level.

\section{Village panchayats}

The village panchayats have effective control on the village environment. There should be proper linkages of extension agencies and village panchayats. Although we are using progressive farmers at grass-root level but village panchayats have more effective strength to influence the farmers. It could be more effective by deciding the grants and the funds to the village panchayats according to the level of agricultural progressiveness at the village.

\section{Cyber extension/ICTs}

It should be available off-line in the villages because the every time on-line access in village area is not possible. So, it is suggested to introduce Kiosks at every village with full information in off-line mode.

Today extension is passing through a major transformation for various domestic and global reasons. The present systems of 
extension in India are the outcome of several efforts and reforms made over the years for improving rural life of the country. Various reforms and developments witnessed in the extension system with great efforts from government and increasing involvement of private sector and NGOs in providing extension services. To secure a better future, the public extension system needs change for better services by structural reforms and improving function through transferring the ownership to and sharing responsibility of its management with the community. While developing any system, the farmer should be kept in focus as player, generator and user of the knowledge. Cost recovery approach and sharing cropping approach should be followed at large level. The social media, agricultural education, village panchayats, off-line initiation of ICT should be helpful for effective extension.

\section{References}

Agarwal, R.G. 2011. Private Interventions in technology dissemination. Pp: 77-78. Westvile publishing House, New Delhi, India.

Anonymous. 2008. Agriclinics and agribusiness centre evaluation study. New Delhi. Retrieved from www.globalagrisystem.com on 10-112015.

Anonymous. 2015. DD Kisan Channel. Retrieved from http:/ddindia.gov.in/DDKisan/Dt.aspx.

Axinn, G.H. 1988. Guide on alternative extension approaches. A reference manual. Pp 3-5. Food and Agriculture Organization of United Nations, Rome.

Bloome, P.D. 1993. Privatization of Extension Lessons. Journal of Extension Education 31:1-4.

Chand, R., Prasanna, P., and Singh, A. 2011. Farm size and productivity: Understanding the strength of smallholders and improving their livelihoods. Economic and political Weekly 46: 52-55.

Feder, G., Willett, A., and Zijp, W. 2001. Agricultural extension-generic challenges and some ingredients for solutions. Pp 313-62. Kluwer Academic Publishers, Massachusetts.

Ferroni, M., and Zhou, Y. 2011. Review of Agricultural Extension in India. Syngenta Foundation for Sustainable Agriculture. Retrieved from www.syngentafoundation.org on 5-112015.

Hagmann, J., Edward, C., and Oliver, G. 2000. Learning about stakeholder/gender differentiation in agricultural research and extension. IFPRI Discussion Paper No. 00141 at Washington, D. C.

Kaur, S. 2005. An assessment of organizational functioning of Agricultural Technology Management Agency (ATMA) in Gurdaspur District of Punjab. M.Sc. Thesis, Punjab Agricultural University, Ludhiana.

Meena, M.S., Singh, K.M., and Swanson, E. 2013. Pluralistic Agricultural Extension System in India: Innovations and Constraints. Retrieved from: SSRN: http://ssrn.com/abstract=2293788 on 611-2015.

Mehta, S.L. 2011. Innovativeness and adoption, Future Agriculture Extension. Pp 56-57. Westvile Publishing House, New Delhi, India.

Mondal, S., and Ray, G.L. 2009. Text book of Entrepreneurship and rural development. Pp 232-69. Kalyani publishers, New Delhi, India.

Mukherjee, A., and Maity, A. 2015. Option for converged extension approach through private extension initiative: A critical concern for Indian agriculture. Current Science 109: 1-7.

Najamuddin, M., and Guliani, M. 2006. Role 
of rural organisations in rural development. Journal of Extension Education 3:49-54.

Prabhakar, I. 2010. Opinion and preferences of farmers regarding Private Extension Services: A study in Tarai region of Uttarakhand. M.Sc. Thesis. GB Pant University of Agriculture and Technology Pantnagar, Uttarakhand, India.

Raj, D.S. 2003. Rural employment and people participation. Rural prosperity oriented programmes, NGOs and people participation. Pp 374-380. Aavishkar Publishers, Jaipur.

Rao, P.N., and Rao, R.V. 2000. Rural development in India: A review. Journal of Kurukshetra. 23:2-6.

Singh, A.K., Singh, L., and Burman, R. 2006. Search of Effective Extension Mechanism. Agricultural Today 9: 3639.

Singh, S. 2002. Contracting out solutions:
Political economy of contract farming in the India. World Development. 30:1621-38.

Sulaiman, R., and Vandenban, A.W. 2003. Funding and delivering agricultural extension in India. Journal of Extension Education 10:21-30.

Sulzer, R. 1989. Agricultural Extension: Rural Development Series. Pp 41-51. Wiley Eastern Publisher, New Delhi, India.

Supe, S.V. 2012. Textbook of Extension Education. Pp 106-08. Agrotech Publishing Academy, Udaipur.

Vandenban, A., and Hawkins, H.S. 1996. Agricultural Extension. Retrieved from http://www.jofamericanscience.org on 5-11-2015.

Vandenberg, H., and Jiggins, J. 2007. Investing in farmers: The impacts of farmer field school. World Develop. 35:663-86.

\section{How to cite this article:}

Kamalpreet Kaur and Prabhjot Kaur. 2018. Agricultural Extension Approaches to Enhance the Knowledge of Farmers. Int.J.Curr.Microbiol.App.Sci. 7(02): 2367-2376. doi: https://doi.org/10.20546/ijcmas.2018.702.289 